\title{
Penerapan Model Pembelajaran SSCS (Search, Solve, Create and Share) Terhadap Kemampuan Berpikir Kritis Siswa
}

\author{
Mifta Erlistiani \\ Universitas Sultan Ageng Tirtayasa - Serang, Banten \\ miftaerlistiani@gmail.com
}

A. Syachruroji

Universitas Sultan Ageng Tirtayasa - Serang, Banten

ahmadsyachruroji@untirta.ac.id

Encep Andriana

Universitas Sultan Ageng Tirtayasa - Serang, Banten

andrianatimenes@gmail.com

\begin{abstract}
The purpose of this research to know the critical thinking ability of the students that using SSCS model. The method used in this research is Kuasi Experiment with the research design Nonequivalent Control Group Design. The research was conducted at SD Negeri Kesaud in academic year 2018/2019. The technique were taken used purposive sampling. In this research, VA class was used as the experiment class and the VB class was used as the control class. The purpose of data analysis techniques to testing the hypotheses using two test and using the right side test. Based on the calculation hypothesis of two parties obtained a score of -2,010 $\leq$ $4,599 \geq 2,010$ if-ttabel $\leq$ thitung $\geq$ ttabel then $\mathrm{H}_{0}$ is rejected and $\mathrm{Ha}$ is accepted. The result of this research can be concluded that the critical thinking ability of students applied the SSCS (Search, Solve, Create and Share) model is better than that of students who applied the Direct Intruction model.
\end{abstract}

Keywords: Critical Thinking, SSCS (Search, Solve, Create and Share), Direct Learning (Direct Instruction)

\section{Pendahuluan}

Pendidikan sekolah dasar merupakan fase terpenting dimana perkembangan anak akan mempengaruhi potensi dirinya secara efektif dalam memecahkan sebuah masalah yang dihadapi. Pembelajaran merupakan kegiatan yang membantu siswa supaya bisa belajar lebih baik. Menurut Susanto (2016: 19) menyatakan bahwa pembelajaran ialah kegiatan belajar yang menadikan siswa menjadi lebih baik.

Ilmu Pengetahuan Alam (IPA) merupakan suatu ilmu mengenai alam serta isinya dan menjadi sebuah pelajaran yang diharuskan untuk dipelajari. Menurut Trianto (2007: 136) menunjukkan ilmu pengetahuan alam ialah sebuah pengetahuan yang dikumpulkan menjadi satu dan sudah diatur dengan baik secara sistematis yang terfokus pada apa yang terjadi pada alam yang dilihat dari adanya kumpulan fakta, metode ilmiah dan sikap ilmiah. Pelajaran IPA di SD ditujukan untuk menanamkan keingintahuan siswa mengenai alam semesta berdasarkan bukti, mengembangkan cara berpikir ilmiah, kemampuan berpikir kritis dan mengambil kesimpulan melatih bersikap objektif, bekerjasama dan saling menghormati. 
Tidak sedikit masalah-masalah bermunculan pada pembelajaran IPA, permasalahan tersebut terjadi karena sering kali penggunaan model pembelajaran yang tidak tepat dengan materi yang diberikan dan tidak mengarahkan peserta didik untuk berpikir kritis. dengan apa yang sedang dipelajari. Kemampuan berpikir kritis sangat penting bagi siswa, karena dengan berpikir kritis siswa akan menggunakan potensi pikiran untuk memecahkan suatu permasalahan dalam kehidupan sehari-hari atau dalam materi-materi pembelajaran. Menurut Susanto (2016: 127) berpikir kritis adalah suatu kegiatan memunculkan ide untuk memecahkan masalah yang di paparkan.

Berpikir kritis penting sekali dimunculkan dalam diri peserta didik karena dengan berpikir kritis peserta didik dapat memahami serta menyelesaikan suatu masalah dan mempu menerapkannya pada kondisi yang berbeda. Menurut Deswani (2009: 119) kemampuan berpikir tingkat tinggi peserta didik bisa lebih dimunculkan melalui kegiatan yang memfokuskan pada pola piker peserta didik. Proses berpikir kritis mampu diterapkan dalam pelajaran IPA SD, karena pada dasarnya pelajaran IPA adalah ilmu mengenai gejala yang terjadi pada alam dengan melakukan kegiatan observasi, eksperimentasi, penyimpulan, teori supaya siswa memiliki pengetahuan mengenai alam sekitar.

Menurut Falah (2018: 26) kemampuan berpikir kritis ini sangat penting untuk dimiliki oleh peserta didik karena di dalamnya terdapat proses aktivitas mental dalam menerima, mengolah, menganalisis, mensintesis, dan mengevaluasi informasi yang didapatkan untuk membuat suatu keputusan atau tindakan dalam memecahkan masalah. Permasalahan yang akan dihadapi oleh peserta didik tidak hanya terdapat dalam pelajaran saja namun dalam kehidupan sehari-hari pun banyak sekali permasalahan yang akan dihadapi oleh peserta didik. Sehingga peserta didik dituntut untuk memiliki kemampuan berpikir kritis agar dapat membuat suatu keputusan atau tindakan yang tepat dalam memecahkan setiap permasalahan yang dihadapi.

Penggunaan model pembelajaran yang sesuai dengan materi yang disampaikan, dapat membuat kemampuan berpikir tingkat tinggi peserta didik menjadi semakin baik lagi dan membuat suasana belajar menjadi variatif dan inovatif. Model-model pembelajaran jumlahnya tidak sedikit dan masing-masing model pembelajaran pasti terdapat manfaat dan kerugiannya. Dan setiap pendidik harus pandai dalam memilih model pembelajaran supaya tujuan dalam belajar bisa terpenuhi. Model pembelajaran SSCS bisa memunculkan keinginan bertanya pada siswa untuk guna menyelesaikan suatu masalah. Sebagaimana menurut Risnawati (2008:58) model pembelajaran SSCS memberikan implikasi yang cukup signifikan pada siswa sehingga dapat mendorong peserta didik untuk berpikir secara kritis, kreatif dan mandiri.

Menurut Baroto (2009: 105) model pembelajaran SSCS ialah model yang menggunakan pendekatan problem solving, di rancang untuk menguatkan kemampuan berpikir tingkat tinggi siswa dan pemahaman terhadap konsep ilmu menjadi meningkat. Hal ini dapat dibuktikan bahwa pada penelitian sebelumnya yang berjudul "Pengaruh Penggunaan Model Pembelajaran SSCS Terhadap Kemampuan Berpikir Kritis Matematika Siswa SDN Bhakti Pekanbaru" dimana kelas yang menggunakan model SSCS kemampuan berpikir kritisnya lebih baik dibandingkan dengan kelas konvensional.

Selain penelitian yang disebutkan di atas, penelitan lain yang berjudul "Keefektifan Model Pembelajaran Seach, Solve, Create, and Share (SSCS) Terhadap Keterampilan Berpikir Kritis Siswa" mendapatkan kesimpulan bahwa kelompok yang menggunakan model pembelajaran SSCS kemampuan berpikir kritisnya lebih baik 
dibandingkan dengan kemampuan berpikir kritis kelompok yang menggunakan model pembelajaran langsung.

Permasalahan-permasalahan banyak ditemukan di sekolah, baik itu dari penggunaan model pembelajaran yang kurang cocok ataupun dari faktor yang lainnya. Dari hasil observasi yang peneliti lakukan di kelas V SDN Kesaud, dalam proses belajar IPA yang terjadi dikelas ialah siswa kurang terlibat dalam kegiatan belajar, karena cenderung kegiatan belajar di dominasi oleh guru. Pada saat kegiatan belajar, siswa hanya menyimak materi yang dijelaskan tanpa diajak untuk berpikir kritis mengenai informasi yang diberikan. Proses berpikir kritis didalam kelas bisa di munculkan dengan cara guru memberikan suatu topik persoalan secara detail dan menyeluruh lalu melakukan identifikasi pada persoalan tersebut dan mendapatkan solusi-solusi yang sesuai secara obyektif. Namun, yang terjadi di lapangan ialah siswa cenderung pasif sehingga pembelajaran menjadi monoton dan terasa membosankan.

Seorang guru pada kegiatan belajar berperan penting pada keberhasilan sebuah tujuan pembelajaran. Sehingga guru diharapkan terampil dan kreatif menyajikan suatu kegiatan belajar yang menyenangkan agar peserta didik mendapatkan pengamalaman secara langsung untuk memahami materi IPA yang dipelajarinya. Pada proses pembelajaran IPA sangat diperlukan model pembelajaran yang pas supaya siswa bisa berpikir kritis dan dapat memahami materi. Salah satu model pembelajaran yang dipandang cocok terhadap kemampuan bepikir kritis siswakelas V pada materi organ gerak manusia yaitu model pembelajaran SSCS. Penggunaan model pembelajaran SSCS diharapkan bisa membuat kegiatan pembelajaran berlangsung menjadi lebih baik sehingga dapat tercapainya tujuan dan timbul sifat kerjasama, saling menerima, berpikir kritis dan saling menghormati.

\section{Metode}

Jenis penelitian yang dilakukan pada penelitian ini ialah penelitian kuantitatif dengan metode kuasi eksperimen. Tujuan eskperimen adalah untuk mengetahui hubungan sebab-akibat dengan cara membandingkan 2 hasil kelompok (Arifin, 2014:68). Penelitian ini menggunakan dua kelompok. Kelompok yang pertama adalah kelompok yang diberi perlakuan menggunakan model pembelajaran SSCS sebagai kelas eksperimen, sedangkan kelas kedua adalah kelas yang pengajarannya menggunakan model pembelajaran Langsung sebagai kelas kontrol.

Dalam sebuah penelitian, populasi dan sampel diperlukan sebagai sumber data. Sugiyono (2014) menjelaskan bahwa populasi terdiri atas objek/subjek yang memiliki keistimewaan untuk dipelajari lalu diambil kesimpulan dan sampel merupakan bagian dari keseluruhan yang dimiliki populasi. Untuk menentukan sebuah sampel, peneliti menggunakan teknik purposive sampling. Menurut Sugiyono (2014: 85), purposive sampling adalah cara pengambilan sampel dengan pertimbangan tertentu. Pertimbangan tertentu tersebut dikarenakan pengelompokkan sampel baru di lapangan sering tidak mungkin dilakukan, adanya perbedaan nilai antara dua kelas yang dipilih sebagai sampel dan adanya kesepakatan dari guru. Partisipan yang terlibat ialah guru dan siswa kelas V SD Negeri Kesaud Kecamatan Kasemen Kota Serang-Banten yang terdiri dari kelas yaitu kelas V A dan Kelas V B yang masingmasing siswanya berjulah 25 siswa. Instrumen pada penelitian ini berupa tes kemampuan berpikir kritis siswa yang berbentuk soal uraian berjumlah 12 soal.

Teknik berupa teknik tes dan non tes. Menurut (Riduwan, 2010:76) Tes ialah berbagai pertanyaan yang biasanya dilakukan untuk mengukur suatu kemampuan atau bakat secara perorangan atau beregu. Tipe tes yang digunakan adalah tes berupa essay untuk mengukur kemampuan berpikir kritis siswa. Tes yang diberikan 
pada penelitian ini berupa pretest dan postest yang terdiri dari soal-soal dari materi yang diajarkan. Teknik non tes pada penelitian ini berupa observasi dan dokumentasi. Observasi Menurut Sugiyono (2014: 145) Observasi dapat dilakukan pada apapun dan tidak terfokus pada manusia. Dalam penelitian ini instrumen observasi dilakukan secara tidak tertata, sebab observasi yang dilakukan tidak disusun secara sistematis. Sedangkan dokumen ialah sebuah catatan kejadian yang telah terjadi (Sugiyono, 2014: 240).

Data yang diperoleh setelah memberi perlakuan adalah nilai tes kemampuan berpikir kritis dari kelas yang dilakukan penelitian. Teknik analisis data pada penelitian ini ialah statistika deskriptif dan inferensial. Menurut Sugiyono (2014: 147) statistik deskriptif digunakan untuk menganalisis data dalam bentuk deskripsi sesuai dengan hasil yang diperoleh tanpa ada maksud membuat kesimpulan. Sedangkan menurut Sugiyono (2014: 148), statistik inferensial ialah teknik untuk menganalisis data sampel yang setelah itu hasilnya diterapkan untuk populasi. Statistik inferensial yang digunakan pada penelitian ini ialah uji prasyarat dimana dalam uji ini terdapat uji normalitas dan uji homogenitas. Selanjutnya dilakukan uji statistik parametrik menggunakan uji t untuk data normal dan homogeny. Lalu dilanjutkan dengan uji hipotesis menggunakan uji dua pihak dan uji pihak kanan.

\section{Hasil}

Pretest dilakukan sebelum diberikannya pembelajaran. Hal ini berguna untuk mengetahui bagaimana kemampuan awal siswa pada masing-masing kelas.

Tabel 1 hasil Pretest dan Posttest Kelas Eksperimen

\begin{tabular}{lcccccc}
\hline $\begin{array}{l}\text { Kelas } \\
\text { Ekperimen }\end{array}$ & $\begin{array}{c}\text { Jumlah } \\
\text { Siswa }\end{array}$ & $\begin{array}{c}\text { Nilai } \\
\text { Terendah }\end{array}$ & $\begin{array}{c}\text { Nilai } \\
\text { Tertinggi }\end{array}$ & $\begin{array}{c}\text { Rata- } \\
\text { rata }\end{array}$ & $\begin{array}{c}\text { Standar } \\
\text { Deviasi }\end{array}$ & Varians \\
\hline Pretest & 25 & 33 & 56 & 43,8 & 7,53 & 61,17 \\
\hline Posttest & 25 & 69 & 83 & 75,52 & 4,55 & 23,19 \\
\hline
\end{tabular}

Tabel 2 hasil Pretest dan Posttest Kelas Kontrol

\begin{tabular}{lcccccc}
\hline $\begin{array}{l}\text { Kelas } \\
\text { Kontrol }\end{array}$ & $\begin{array}{c}\text { Jumlah } \\
\text { Siswa }\end{array}$ & $\begin{array}{c}\text { Nilai } \\
\text { Terendah }\end{array}$ & $\begin{array}{c}\text { Nilai } \\
\text { Tertinggi }\end{array}$ & Rata-rata & $\begin{array}{c}\text { Standar } \\
\text { Deviasi }\end{array}$ & Varians \\
\hline Pretest & 25 & 33 & 50 & 42,02 & 5,33 & 28,91 \\
\hline Posttest & 25 & 64 & 78 & 69,56 & 3,78 & 18,80 \\
\hline
\end{tabular}

Berdasarkan tabel 1 dan 2 diatas dapat disimpulkan pada diagram 1 bahwa terlihat perbedaan rata-rata kemampuan berpikir kritis kedua kelas.

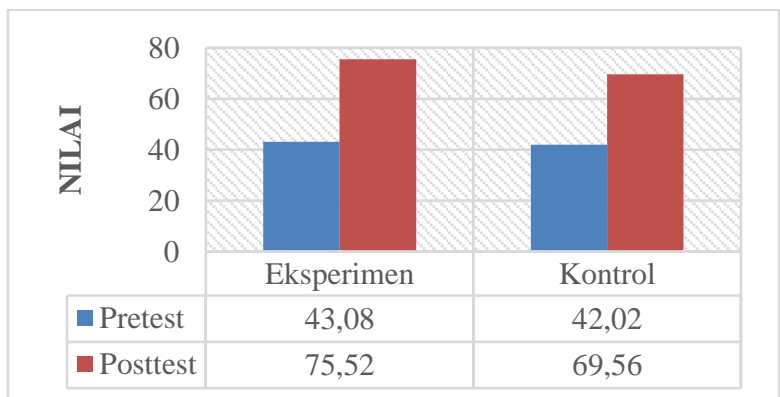

Diagram 1 Nilai Rata-Rata Pretest dan Posttest Kemampuan Berpikir Kritis Peserta Didik Kelas Kontrol dan Kelas Eksperimen

Untuk statistik inferensial, peneliti melakukan uji prasyarat analisis data yang yaitu uji normalitas dan uji homogenitas. Pengujian normalitas dilakukan untuk mengetahui bahwa sampel yang diambil berasal dari populasi yang normal. 
Tabel 3 hasil uji normalitas Pretest Kelas Eksperimen dan Kelas Kontrol

\begin{tabular}{lcccc}
\hline Pretest & DK & $\boldsymbol{X}^{2}$ hitung & $\mathbf{X}^{\mathbf{2}}$ tabel & Keputusan \\
\hline Eksperimen & 5 & 9,31 & 9,488 & Normal \\
\hline Kontrol & 5 & 4,99 & 9,488 & Normal \\
\hline
\end{tabular}

Tabel 4 hasil uji normalitas Posttest Kelas Eksperimen dan Kelas Kontrol

\begin{tabular}{lcccc}
\hline Posttest & DK & $\boldsymbol{X}^{2}$ hitung & $\mathbf{X}^{2}$ tabel & Keputusan \\
\hline Eksperimen & 5 & 9,480 & 9,488 & Normal \\
\hline Kontrol & 5 & 5,56 & 9,488 & Normal \\
\hline
\end{tabular}

Dari tabel diatas terlihat bahwa uji normalitas dari kedua kelas berdistribusi normal. Selanjutnya ialah pengujian homogenitas dilakukan untuk mengetahui bahwa sampel berasal dari populasi yang sama.

Tabel 4 hasil uji homogenitas Pretest Kelas Eksperimen dan Kelas Kontrol

\begin{tabular}{|c|c|c|c|c|}
\hline Pretest & varians & $F_{\text {hitung }}$ & $F_{\text {tabel }}$ & Keputusan \\
\hline Eksperimen & 61,17 & & & \\
\hline Kontrol & 28,91 & 0,47 & 1,96 & Ho \\
\hline
\end{tabular}

Tabel 5 hasil uji homogenitas Posttest Kelas Eksperimen dan Kelas Kontrol

\begin{tabular}{|c|c|c|c|c|}
\hline Posttest & varians & $F_{\text {hitung }}$ & $\mathbf{F}_{\text {tabel }}$ & Keputusan \\
\hline Eksperimen & 23,19 & \multirow{2}{*}{0,81} & \multirow{2}{*}{1,96} & \multirow{2}{*}{ Homogen } \\
\hline Kontrol & 18,80 & & & \\
\hline
\end{tabular}

Hasil uji normalitas dan homogenitas pretestdan posttest pada kelas kontrol dan kelas eksperimen yaitu didapatkan data yang berdistribusi normal dan homogen. Maka selanjutnya dilakukan uji hipotesis. Untuk menguji hipotesis pihak kanan bahwa skor akhir kemampuan berpikir kritis kelas eksperimen terjadi peningkatan dari kelas kontrol, maka dilakukan uji kesamaan rata-rata posttest dengan menggunakan uji-t. diperoleh nilai t-hitung $=4,599$ dan t-tabel 2,010 sehingga 4,599 $>2,010$. Sesuai dengan kriteria pengujian, artinya $\mathrm{H}_{0}$ ditolak dan $\mathrm{H}_{a}$ yang diterima. Data hipotesis ini menunjukkan bahwa kemampuan berpikir kritis peserta didik yang diterapkan model pembelajaran SSCS lebih baik dari peserta didik yang diterapkan model pembelajaran langsung.

\section{Pembahasan}

Model pembelajaran SSCS menekankan kemampuan berpikir kritis siswa dalam menyelesaikan suatu masalah. Pada tahap search siswa diberikan permasalahan dalam bentuk soal lalu dituntun untuk melakukan pemikiran dalam menyelesaikan soal melalui pengalaman ataupun buku sumber bersama teman sekelompok. Ini sesuai dengan pendapat Irwan (2011: 4) bahwa siswa dituntut untuk memperoleh informasi yang terkait dengan pembelajaran melalui buku sumber ataupun pengalamannya dalam kehidupan sehari-hari. Pada tahap search ini, siswa mampu memberikan penjelasan sederhana, membangun keterampilan dasar dan mengatur strategi dan taktik melalui buku sumber dan bertanya dengan teman sekelompok atau guru.

Tahap solve siswa mengerucutkan jawaban yang telah diperoleh pada tahap sebelumnya dan memilih langkah penyelesaian yang paling tepat. Setelah siswa dapat mengidentifikasi masalah pada tahap search, siswa dituntun untuk berdiskusi bersama dengan teman sekelompoknya untuk menentukan jawaban-jawaban tersebut. Diskusi dalam kelompok tersebut memungkinkan siswa bertukar pikiran dan menyampaikan ide-ide dengan teman sekelompoknya sehingga mengasah kemampuan berpikir kritis pada aspek memberikan penjelasan lebih lanjut dan akan terciptanya sikap saling menghormati. Hal itu sesuai dengan yang dikatakan Irwan (2011: 4) bahwa dalam merencanakan pemecahan masalah, siswa secara 
berkelompok dituntun untuk berdiskusi membuat perencanaan penyelesaian masalah. Setelah tahap solve, dilanjutkan dengan tahap create yaitu siswa menulis jawaban yang sudah di diskusikan bersama sebagai hasil akhir dalam menjawab pertanyaan. Dalam kegiatan ini peserta didik menentukan jawaban dari hasil bertukar pikiran yang telah di setujui oleh semua anggota kelompok. Pada tahap ini mampu melatih kemampuan berpikir kritis siswa dalam aspek menyimpulkan dengan membuat kesimpulan secara benar dab logis dan mengatur strategi dan taktik. Hal itu sesuai dengan yang dikatakan Irwan (2011: 4) bahwa pada tahap create siswa dituntun untuk mampu menerapkan rencana pemecahan masalah yang telah dipilih pada tahap sebelumnya.

Tahap yang terakhir ialah tahap share. Pada tahap ini salah satu dari kelompok mempresentasikan hasil diskusi dengan memberi penjelasan yang paling sederhana agar data mudah dipahami oleh teman sekelas dan didiskusikan kembali jawaban dari masing-masing kelompok yang berbeda. Pada tahap ini siswa yang presentasi dan siswa yang menyimak bisa saling bertukar pikiran, berbagi ide dan masukan yang dapat melatih kemampuan siswa dalam mengkomunikasikan sebuah gagasan. Hal ini sesuai yang dikatakan Irwan (2011: 4) bahwa mengkomunikasikan penyelesaian yang diperoleh pada fase create ialah siswa mempresentasikan hasil ataupun kesimpulan yang telah diperoleh selama bekerja kelompok kepada siswa lainnya di depan kelas.

Pada kelas eksperimen, saat proses pembelajaran berlangsung siswa fokus untuk memecahkan masalah dengan cara berdiskusi bersama dengan teman sekelompoknya. Setiap anggota kelompok memberikan ide tau gagasan baru yang setelah itu akan ditanggapi oleh teman sekelompoknya untuk diberikan masukanmasukan apabila ide atau gagasan tersebut masih kurang untuk mendapatkan jawaban yang sesuai untuk menjawab pertanyaan. Sesuai pendapat Risnawati (2008: 65) yang mengungkapkan bahwa model pembelajaran SSCS memiliki keunggulan diantaranya memberikan kesempatan bagi siswa untuk mendapatkan pengalaman langsung pada proses pemecahan masalah, mengolah informasi dan menggunakan keterampilan berpikir tingkat tinggi. Cara seperti ini pembelajaran akan sangat bermakna sehingga dapat menghasilkan pembelajaran yang memuaskan. Hal tersebut terbukti dari presentase yang ada, mengalami sebuah peningkatan dari hasil pretest dan postest. Dimana hasil rata-rata pretest yaitu 43,8 dan hasil ratarata posttest yaitu 75,52 .

Penelitian yang dilakukan pada kelas kontrol menerapkan model pembelajaran langsung. Pada pembelajaran tersebut, kegiatan belajar didominasi oleh guru, yaitu guru memberikan materi dengan metode ceramah, akibatnya pembelajaran menjadi kurang efektif. Siswa hanya menyimak penjelasan guru sehingga kurang terjadinya interaksi antara siswa dan guru. Ketika mengerjakan soal yag ada pada LKPD terlihat di setiap kelompok belum adanya rasa saling membantu satu sama lain antar kelompok, anggota yang lainnya hanya melihat dan memperhatikan tanpa berkontribusi seara aktif dengan anggota kelompok yang lain. Pada kelas yang diterapkan model pembelajaran langsung, ada peningkatan dilihat dari nilai pretest dan posttest. Dimana hasil rata-rata pretest yaitu 42,02 dan hasil rata-rata posttest yaitu 69,52 .

Berdasarkan penjelasan pembahasan diatas, dapat disimpulkan bahwa terlihat adanya peningkatan kemampuan berpikir kritis siswa yang menerapkan model SSCS dengan kemampuan berpikir kritis siswa yang menerapkan model pembelajaran langsung. Hal ini terlihat dari hasil uji t dua pihak nilai posttest, diperoleh nilai t-hitung $=4,599$ dan t-tabel 2,010 sehingga 4,599 $>2,010$. Bisa ditarik kesimpulan bahwa $\mathrm{H}_{0}$ ditolak dan $\mathrm{H}_{a}$ yang diterima. Data hipotesis ini menunjukkan bahwa kemampuan berpikir kritis peserta didik yang diterapkan model 
pembelajaran SSCS lebih baik dari peserta didik yang diterapkan model pembelajaran langsung. Data ini dapat diperoleh karena adanya peningkatan hasil tes awal dan tes akhir dari kedua model yang diterapkan.

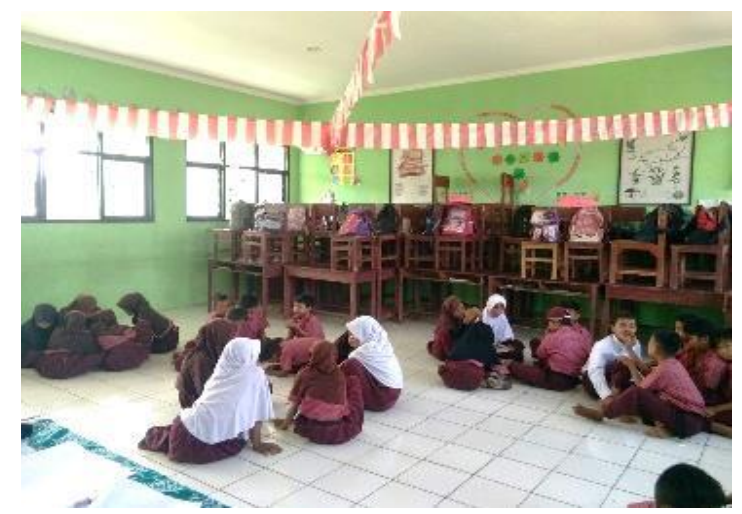

Gambar 1. Pembelajaran pada kelas eksperimen

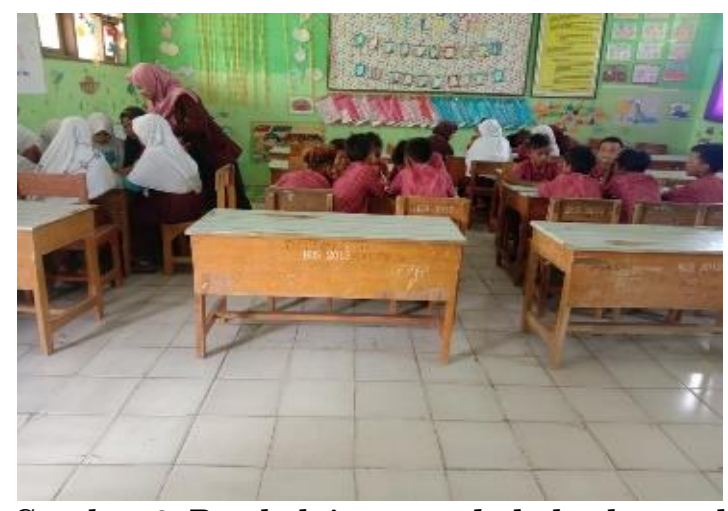

Gambar 2. Pembelajaran pada kelas kontrol

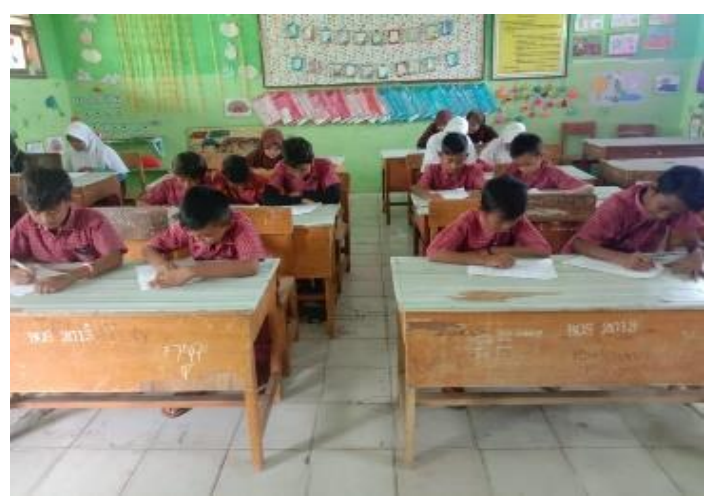

Gambar 3. Pengerjaan soal posttest

\section{Simpulan}

Setelah dilakukan perhitungan data dan didapatkan hasil penelitian yang sudah dilakukan, maka dapat disimpulkan: Model pemelajaran yang diterapkan di kelas eksperimen (model pemelajaran SSCS) dan dikelas kontrol (model pembelajaran langsung) terlihat adanya peredaan kemampuan berpikir kritis pada peserta didik. Terlihat pada saat proses pembelajaran, siswa yang diberi perlakuan model pembelajaran SSCS lebih aktif dalam proses diskusi dengan bertukar pendapat yang dapat melatih kemampuan berpikir kritis ssiswa, melatih kemampuan siswa dalam membuat kesimpulan Dari hasil perhitungan uji hipotesis pihak kanan dengan cara 
t-hitung $\geq$ t-tabel yaitu 4,599 > 2,010 dapat dikatakan bahwa kemampuan berpikir kritis peserta didik yang diterapkan model SSCS terlihat lebih baik dibandingkan dengan kemampuan berpikir kritis peserta didik yang diterapkan model pembelajaran langsung.

Berdasarkan hasil penelitian yang telah dilakukan, maka peneliti mengajukan beberapa masukan diantaranya: 1) Bagi sekolah disarankan, untuk lembaga sekolah agar menyertakan atau memberikan kesempatan yang luas kepada pendidik dalam sebuah pelatihan pendidikan. Semakin banyak pelatihan pendidikan yang diikuti oleh pendidik, maka akan semakin banyak juga pengetahuan pendidikan baru yang bisa didapatkan dari kegiatan tersebut. Karena sejatinya pendidikan akan semakin maju seiring berkembangnya zaman. Kita jangan terlalu nyaman oleh pendidikan yang begitu-begitu saja, kita harus menciptakan inovasi baru dalam sebuah proses pembelajaran untuk menciptakan generasi penerus bangsa yang cerdas dan memiliki kemampuan, 2) Bagi guru disarankan untuk pendidik yang terdapat disekolah, apabila kita sudah mengenali kemampuan masing-masing peserta didik yang cenderung kritis, kita perlu memanfaatkan kemampuan peserta didik untuk menunjang ketercapaian proses pembelajaran. Perlunya persiapan seperti menyusun model pembelajaran sebelum memulai pembelajaran dirasa sangat penting agar tercapainya tujuan pembelajaran pada saat proses belajar mengajar. Seperti model pembelajaran yang peneliti gunakan, penggunaan model pembelajaran SSCS terhadap mata pelajaran IPA dirasa sangat sesuai diterapkan untuk melihat kemampuan berpikir kritis peserta didik, 3) Bagi peneliti selanjutnya disarankan kepada peneliti-peneliti selanjutnya, sebelum melakukan penelitian diharapkan dapat mengetahui terlebih dahulu permasalahan yang terjadi disekolah.Suatu permasalahan dapat diketahui melalui kegiatan wawancara, observasi dan lain sebagainya. Jika kita sudah mengetahui permasalahan apa yang terjadi disekolah, maka akan mudah untuk kita mendapatkan solusi yang dirasa tepat dalam menyelesaikan permasalahan tersebut.

\section{Referensi}

Baroto, dkk. (2009). Pengaruh Model Pembelajaran PBL dan Model Pembelajaran SSCS Ditinjau dari Kreativitas dan Intelegensi Siswa. Tesis. Surakarta: Universitas Sebelas Maret.

Deswani. (2009). Proses Keperawatandan Berpikir Kritis. Jakarta: Salemba Medika.

Falah, dkk. (2018). Peningkatan Kemampuan Berpikir Kritis Peserta Didik Melalui Model Pembelajaran Search, Solve, Create and Share (SSCS) Berbasis Etnosains, 2 (1), 25-32.

Irwan. (2011). Pengaruh Pendekatan Problem Posing Model Search, Solve, Create and Share (SSCS) Dalam Upaya Meningkatkan Kemampuan Penalaran Matematis Mahasiswa Matematika, 12 (1), 1-12.

Hatari, N., dkk. (2016). Keefektifan Model Pembelajaran Seach, Solve, Create, and Share (SSCS) Terhadap Keterampilan Berpikir Kritis Siswa. USEJ 5 (2).

Risnawati. (2008). Strategi Pembelajaran Matematika. Pekanbaru: Suska Press.

Rhozy, F., dkk. (2016). Pengaruh Penerapan Model SSCS Berbantuan Bahan Ajar Bermuatan Karakter Untuk Meningkatkan Hasil Belajar Fisika Siswa Kelas XI SMAN Padang. Padang: 7.

Sugiyono. (2014). Metode Penelitian Pendidikan Pendekatan Kuantitatif, Kualitatif, dan $R \& D$. Bandung: Alfabeta.

Susanto, A. (2016). Teori Belajar dan Pembelajaran di Sekolah Dasar. Jakarta: Prenadameda Group.

Trianto. (2007). Model-model Pembelajaran Inovatif Berorientasi Kontrutivistik. Jakarta: Prestasi Pustaka. 